\title{
A Short Overview of China's Higher Education, and Students Global Mobility
}

\author{
Jean Philippe Berlie \\ Liberal Arts, Education University of Hong Kong, Hong Kong, China \\ Email address: \\ berliej@hotmail.com \\ To cite this article: \\ Jean Philippe Berlie. A Short Overview of China's Higher Education, and Students Global Mobility. Higher Education Research. \\ Vol. 4, No. 4, 2019, pp. 52-55. doi: 10.11648/j.her.20190404.11
}

Received: July 31, 2019; Accepted: August 29, 2019; Published: September 16, 2019

\begin{abstract}
Background: China launched in 2013 a global project called the One Belt One Road (OBOR), renamed later the Belt and Road Inititive. This idea of modernization also exists for the higher education. Objective: This is an overview of China's higher education and prospects of development. Method: Reading and enquiry shows that China's higher education is global and has ambitious programs on higher education. Result: Between 1990 and 2010, in just twenty years, China made unbelievable progresses in higher education and stands probably unique in the world history for its progresses. The number of universities in China was 1908 in 2007, 2491 in 2013 and 2631 in 2017 (Statista 2019). This number has increased constantly over the past decade. In 2012, 400,000 of mainland China students left and studied abroad, in 2013 this number increased to 420,000 and became 550,000 in 2016 (China's Minister of Education). The number of foreign students who came to study in China was 320,000, 380,000 and 440,000 in 2012, 2013 and 2016 respectively. In 2019, the first university of China was Tsinghua University in Beijing, followed by Beijing University, Zhejiang University and Shanghai Jiao Tong University. In the world university ranking table, Tsinghua was respectively ranked the $71^{\text {st }}$ in $2012,52^{\text {nd }}$ in $2013,30^{\text {th }}$ in 2018 and $22^{\text {nd }}$ in 2019 . There are huge changes in higher education in China, and student mobility in higher education is high. Conclusion: This paper compares globalization, and study in particular glocalization. China certainly accepts the fact that it is more convenient to retain some Chinese local tradition, and keeps the best norms of the international higher education adapted to the Chinese cultural concepts. This is probably why China's higher education has reached its present high level.
\end{abstract}

Keywords: China (The People's Republic of China), Globalization, Glocalization, Higher Education, Sinicization, Student Mobility

\section{Introduction}

This article advocates student mobility as a part of the present people's globalization. Many students go overseas to study in tertiary education. Per year, in China, half a million of them study abroad.

The second axe of research is the importance of glocalization. What is it? Why advocating glocalization in international higher education? China in particular has successfully constructed new universities and up-graded many others in keeping the best of its local culture and cultural history.

It is sure that glocalization is an essential tool to develop the quality of learning. A good academic level is important. "Glocalization focuses on enhancing the quality of learning for local and global learner cohorts through mutual understanding and shared values at a deep level of academic and social engagement" [5].

\section{Method}

The approach What, Why, How, Who and When will be used to try to understand how global is China's higher education and China's ambitious program on higher education.

\section{Result}

Reforms in China and the fantastic development of the higher education in the PRC.

What is the question of Chinese students going overseas? It is a sensitive topic in a time of US-China trade war; we have to understand China's higher education, the reforms of 
Deng Xiaoping and why and how China is global in higher education. Deng's opening-up policy in 1978, was also a new era of diplomacy in particular in the USA to match China's domestic agenda of economic development associated Foreign Direct Investments (FDI). China became the world factory in a short time. It is the most important Economic development in few years in the world history.

Education, and in particular higher education, was not forgotten. What is the number of universities in mainland China? They were 1908 in 2007, 2491 in 2013 and 2631 in 2017 (Statista 2019). This number has increased constantly over the past decade. In contrast, the number of high schools in China was "receding, from about 78,000 schools in 2005 to 65,645 schools in 2015 ".

In 2012, 400,000 of mainland China students left and studied abroad, in 2013 this number increased to 420,000 and became 550,000 in 2016 (China's Minister of Education: MOE). The number of foreign students who came to study in China was 320,000, 380,000, 440,000 and 489, 200 in 2012, 2013, 2016 and 20017 respectively [12]. The current annual percentage of increase is 10 percent, so, there are a significant growing number of international students studying in China. These foreign students join in particular universities in Beijing, Shanghai, Jiangsu, and Zhejiang. It is significant that "The number of students from BRI countries, which accounted for $64.85 \%$ of all international students in China, was 317,200 in 2017" (ibid.) It is evident that for foreign students coming for a master or " $\mathrm{Ph}$. $\mathrm{D}$. degree across a widening range of disciplines," the scholarships granted by the Chinese government are particularly attracting.

China's allocated budget for the education of international students has been increased by 16.08 percent in 2018 to "more than 3 billion yuan-Renminbi (\$469 million)", according to a report by the Ministry of Education. China's target is "hosting 500,000 international students by 2020 ". "In 2017, 58,600 students from 180 countries were awarded Chinese government scholarships", accounting for 11.97 percent of the overall total (Higher education budget 2018). It's also much easier for these foreign students in China to have part time jobs.

In 2019, does the US-China trade war will affect the current high number of mainland Chinese students studying overseas? Does it reflects more 'globalization' in Chinese higher education than elsewhere in the world?

Chinese students abroad made up the largest group of international students in the USA. For international students, "the adaptation variables include the following items: housing communication with Americans, dating and marriage mater, discrimination, finance, food, immigration, studies, communication..." and contact with Americans in general $[13,14]$.

Some years ago, "PRC students find American culture quite different from their own and it [was] difficult for them to adjust and socialize with Americans [5] (1991: 9)". China is changing and it is not sure that in 2019 the "adjustment" of the Chinese students is not improving. However, like in America, the numerous mainlander students in Hong Kong
University like to stay among themselves.

It is right that "many adaptation problems of international students remain relatively unknown to academic and support staff of universities and colleges (ibid.: 15)". The language problem also keeps the overseas students difficult to participate in social activity. PRC students may have serious initial language problem with English. Long ago, I also remember the great difficulty of a Chinese colleague who studied in the USA, after WWII, who found a problem in understanding the social distance between whites and nonwhites he observed.

These cultural differences may exist, but we can also say that, in the present global world of the $21^{\text {st }}$ century, that the immersion with another culture of foreign students studying abroad in their host countries constitutes an exceptional advantage in a time of current international mobility.

\subsection{Glocalization in Higher Education}

Why there is a question mark for the term "glocalization?" Many academics do not like this term and prefer globalization. Local development of higher education with local cultural values is valuable. How could we forget that the concept glocalization, probably introduced in the 1990s and developed by Robertson (1995) in the 2000s, because it is used in a remote district of Assam on the northern bank of the mighty Brahmaputra River [3] It is interesting to note that China's Belt and Road was launched by President Xi Jinping the same year. A good definition of this term in higher education is given by [5] (2019: 107) which is a response to "the little time or respect for local traditions" in many universities which are not interested at all by glocalization and are probably more concerned by their position in the world university ranking table. The present global world is "spatial and temporal", geographical and historical, the higher education needs all these concepts and interpretations and glocalization "has the definite advantage of making the concern with "space" as important as the focus upon temporal and historical issues" [11] (2012: 205).

\subsection{Transformation}

During some 5000 years China invented Sinicization to assimilate and integrate a part of its numerous minorities which have thanks to China's glocalization improved and enriched the national Chinese culture. This sort of cultural improvement also enabled China's higher education which uses the best of the current international higher education standard, but keeps its "glocalized" own local culture which helped to transform China's higher education between 1990s and the present time.

\section{Discussion}

How goes the harmful trade war between the USA and China in 2019? "The US and China are escalating their restrictions on access by academics from the other side, which poses serious problems for scholarship and bilateral 
relations" [14]. Zhu Feng of Nanjing University and Wu Baiyi of Beijing had mid-April 2019 their "multi-year and multi-entry visas' revoked. Consequently "Trump's China adviser Michael Pillsburg" was not authorized to attend a conference in Beijing. Both governments to allow academic exchanges were advised to "enhance mutual understanding." Preventing good international understanding will also harm mainland Chinese students studying in America and US students to take advantage of the direct Chinese knowledge of China's excellent universities and "dialogue among academic experts" of both countries. Visa war is "systematically deteriorating relationship." The USA-China trade war may create a long-term risk of "hard-to-reverse economic stagnation" (Dan Steinbock, SCMP June 20, 2019). It will affect the high number of mainland Chinese students studying overseas \& Overseas Non-Chinese coming to study in China. "Compared to pre-2008 crisis levels, world economic growth has already plummeted by half and is at risk of a long-term, hard-to-reverse stagnation. Returning to global integration and multilateral reconciliation could dramatically change the scenario."

\section{Conclusion}

The extraordinary progresses of China's higher education were done in a very short time, in twenty years (1990-2010). In a time of tertiary education's globalization, many students want to go to Beijing or Shanghai's universities, in particular African and US students. In a reciprocal gesture of good will, the attraction of the United States is particularly strong among Chinese students and China's target is hosting 500,000 international students by 2020 .

The important number of Master and $\mathrm{PhD}$ scholarships offered by the Ministry of Education of China is significant (see the Annex). We hope that both the USA and China will solve the conundrum of the current trade war and, doing so, will evidently improve the present globalization and visa problem of talented Chinese and American academics and students.

\section{Recommendations}

We propose some recommendations.

Of course it is a trend to have a growing number of international students studying in China, but also Chinese students wanting to upgrade their education and study in the USA. This is favorable to international mutual understanding and peace in the world following academic exchanges.

"Keep US-China relations on an even keel as the relationship reconfigure itself to better reflect current political and economic realities. Students from both countries eventually will become future leaders in government, business, and academia; hopefully, greater mutual understanding developed through cooperative learning and cross-cultural exchange will help to soften some of the current mistrust and pave the way for more reasoned and balanced conversations in the years ahead" [10] (2019: 7).

\section{References}

[1] Biggs, J. 1996. Western Misconceptions of the ConfucianHeritage Learning Culture, in D. A. Watkins and J. B. Biggs et al. (eds) The Chinese Learner: cultural, psychological and contextual influences, 45-67. Hong Kong: Comparative Education Research Centre, University of Hong Kong.

[2] Feng, J. 1991. The Adaptation of Students from the People's Republic of China to an American Academic Culture. http://www.eric.ed.gov/PDFS/ED329833.pdf (accessed March 10, 2019), 1-16.

[3] Globalization: Globalization and Education of Manipur in the Context of Look East Policy: Policies and their Absence, edited by Ningthouja Lancha (ed.), Vol. VIII, Issue I, Imphal; Look East Policy and North-East India: Challenges and Opportunities in M. C. Behera (ed.). 2013. [India] North-East and Globalization. Glocalization: Wahengbam, Sonia. 2013. The Trends and Impact of Indian Reality Shows in Context of Media Glocalisation in the Seminar Globalization to Glocalisation, English Department, Bodoland University, Kokrajhar, Assam, 4 October 2013.

[4] Habibul H. Khonder. Glocalization of higher education in Victor Faessel et al. (eds.). The Oxford handbook of global studies. OUP, 107.

[5] Henze, Juergen and Jiani Zhu. Feb. 2012. Current Research on Chinese Students Studying Abroad in Research in Comparative and International Education Vol. 7 Nr. 1, 90-103.

[6] Nicotra, A., and Patel, F. 2016. Contesting the political economy of higher education: Educating the good citizen. Journal of International and Global Studies, 7 (2), 22-39. http://www.lindenwood.edu/jigs/docs/volume7Issue2/essays/2 2-39.pdf (accessed March 10, 2019).

[7] Higher education budget (2018) and international student increased budget: China boosts international student budget by $16 \%$ as student target nears https://thepienews.com/news/china-boosts-internationalstudent-budget-by-16-as-student-target-nears/ (accessed March 11, 2019).

[8] Patel, Fay. Apr. 2017. Deconstructing internationalization: Advocating glocalization in international higher education. Journal of International and Global Studies, Vol. 8 Nr. 2, 64-82.

[9] Patel, F. and Lynch, H. 2013. Glocalization as an alternative to internationalization in higher education: Embedding positive 'glocal' learning perspectives. International Journal of Teaching and Learning in Higher Education (IJTLHE), 25 (2), 223-230. http://www.isetl.org/ijtlhe/past2.cfm? $\mathrm{v}=25 \& \mathrm{i}=2$ and https://files.eric.ed.gov/fulltext/EJ1016539.pdf (accessed March 10, 2019).

[10] Postiglione, Gerard A. and Denis Simon. 2019. China-US cooperation in higher education: A critical stabilizer in International Higher Education Nr 96 Winter 2019, 5-7. DOI: http://dx.doi.org/10.6017/ihe.2019.96.10796 (accessed April 23, 2019).

[11] Robertson, R.1995. Glocalization: Time-space and homogeneity-heterogeneity in M. Featherstone, S. Lash, and R. Robertson (eds.). Global modernity. London: Sage, 25-44. 2012. Globalisation or glocalisation?, Journal of International Communication, 18: 2, 191-208. 
[12] Students (MOE 2018-04-03) from abroad in China (increasing number):

en.moe.gov.cn/News/Top News/201804/t20180403 332258.h tml (accessed April 23, 2019).

[13] Surdam, J. C. and Collins J. R. Adaptation of international students: A cause for concern in Journal of College Student Personnel 25 (3), 240-245.
[14] Visa War 2019: Shambaugh, David. 2019. Harmful 'visa war.' SCMP April 23, 2019, A4. https://www.scmp.com/comment/insightopinion/article/3007149/when-china-and-us-wage-visa-waragainst-each-others (accessed April 23, 2019). 